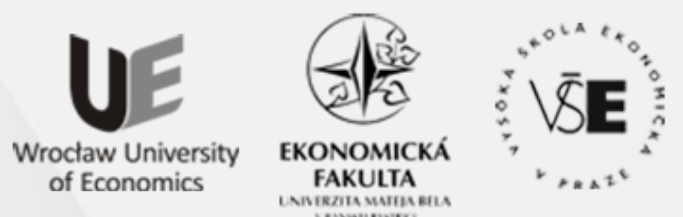

Conference Proceedings

Full TeXT PAPERS

edited by

Zofia Rusnak and Beata Zmyślona

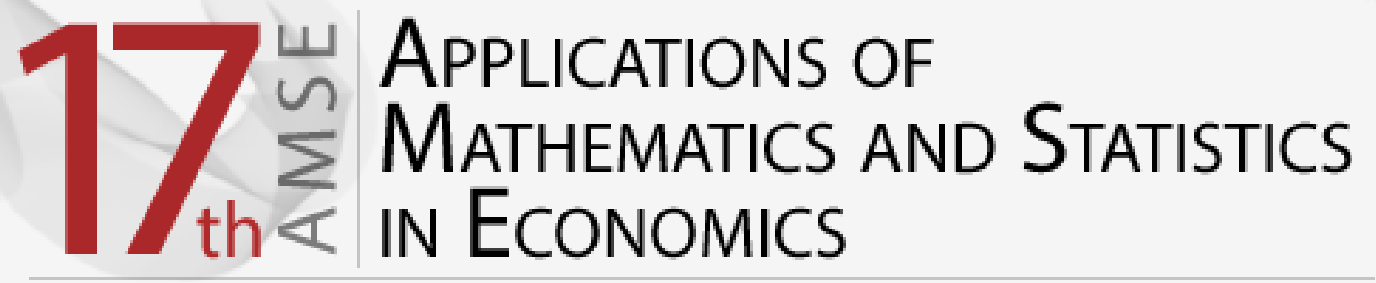

International Scientific Conference | Poland • 27-31 August 2014 
Scientific Committee

Richard Hindls, Stanislava Hronová, Rudolf Zimka, Walenty Ostasiewicz, Emília Zimková, Zofia Rusnak, Martin Bod'a

Organizing Committee

Beata Zmyślona, Cyprian Kozyra, Grzegorz Rogoziński, Kristýna Vltavská

\section{Reviewers}

Milan Bašta, Diana Bílková, Martin Bod'a, Joanna Dębicka, Tomáš Fiala, Jakub Fischer, Stanisław Heilpern, Karel Helman, Lenka Hudrlíková, Miroslav Hužvár, Nikola Kaspř́ková, Alena Kaščáková, Kamil Kladívko, Jindřich Klůfa, Pavol Král', Katarzyna Kuziak, Jana Langhamrová, Ivana Malá, Tomáš Marcinko, Luboš Marek, Miloš Maryška, Petr Mazouch, Zofia Mielecka-Kubień, Witold Miszczak, Petr Musil, Gabriela Nedelová, Walenty Ostasiewicz, Iva Pecáková, Viera Roháčová, Zofia Rusnak, Mária Stachová, Jana Špirková, Šárka Šustová, Jana Tepperová, Vladimír Úradníček, Kristýna Vltavská, Michal Vrabec, Dariusz Wawrzyniak, Henryk Zawadzki, Jaroslav Zbranek, Tomáš Zeithamer, Martin Zelený, Jan Zeman, Rudolf Zimka, Emília Zimková, Pavel Zimmermann, David Žižka

Layout

Martin Bod'a, Beata Zmyślona, Grzegorz Rogoziński

Front page design

Grzegorz Rogoziński

CD cover design

Beata Dębska

Articles published in the form submitted by the authors

All rights reserved. No part of this book may be reproduced in any form or in any means without the prior permission in writing of the Publisher

(C) Copyright by Wrocław University of Economics Wrocław 2014

ISBN 978-83-7695-421-9

Wydawnictwo Uniwersytetu Ekonomicznego we Wrocławiu

53-345 Wrocław, ul. Komandorska 118/120 www.ue.wroc.pl

Sprzedaż książek tel./fax 71 36-80-602

e-mail: econbook@ue.wroc.pl www.ksiegarnia.ue.wroc.pl 


\section{Contents}

Foreword

Diana Bílková: TL-Moments: Analogy of Classical L-Moments

Dagmar Blatná: Application of Robust Regression in the Analysis of Internet Access in European Countries

Martin Bod’a, Mária Kanderová: Rebalancing Issues in Tracking Error Variance Minimization

Martin Bod'a, Viera Roháčová: Application of Six Sigma Ideas to Timing Decisions at Financial Markets

Anton Dekrét, Rudolf Zimka: On the Price Hartwick's Task and Its Inverse in a Dynamic Model of an Economy with Exhaustible Resources

Joanna Dębicka, Agnieszka Marciniuk: Comparison of Reverse Annuity Contract and Reverse Mortgage on the Polish Market.

Petra Dotlačilová, Jitka Langhamrová: The Influence of Mortality Models for the Expected Future Life-time of Older People

Marek Ďurica, Lucia Švábová: Delta and Gamma for Chooser Options.

Vlastimil Farkašovský: New Concept of Pension Funds Performance Evaluation

Albert Gardon: The Normality of Weekly Relative Changes of the Freight Rate in Container Shipping.

Mária Grausová, Miroslav Hužvár, Jana Štrangfeldová: Healthcare Systems Efficiency in the Visegrád Group.

Stanisław Heilpern: Multiple Life Insurance - Pension Calculation

Alena Kaščáková, Gabriela Nedelová: Changes in Slovak Households' Economy

Igor Kollár, Pavol Král', Peter Laco: Methodology for Assessing Website Improvement in Corporate Environment.

Maciej Kostrzewski: Some Method of Detecting the Jump Clustering Phenomenon in Financial Time Series.

Cyprian Kozyra, Beata Zmyślona, Katarzyna Madziarska: Complementary Objective and Subjective Measures of Hospital Services Quality...

Pavol Král', Mária Stachová, Lukáš Sobíšek: Utilization of Repeatedly Measured Financial Ratios in Corporate Financial Distress Prediction in Slovakia

Ivana Malá: The Use of Finite Mixture Model for Describing Differences in Unemployment Duration

Lukáš Malec: Studying Economics and Tourism Industry Relations by Smooth Partial Least Squares Method Depending on Parameter. 
Tomáš Marcinko: Consequences of Assumption Violations Regarding Classical Location Tests.

Edyta Mazurek: The Income Tax Progression Depending on Social Insurance Contribution in Poland.

Petr Musil, Jana Kramulová, Jan Zeman: Regional Consumption Expenditures: An Important Starting Point for Regional Input-output Tables.

Katarzyna Ostasiewicz, Walenty Ostasiewicz: Good Life: From Political to Human Economy

Anna Sączewska-Piotrowska: Analysis of Poverty Transitions in Poland Using Multilevel Discrete-Time Event History Models

Martina Šimková, Petra Švarcová: Disadvantaged University Students in the Czech Republic.

Michal Široký: The Use of Short-term Business Statistics for Quarterly GDP Flash Estimates in the Czech Republic

Zdeněk Šulc, Hana Řezanková: Evaluation of Recent Similarity Measures for Categorical Data.

Lucia Švábová, Marek Ďurica: The Relationship Between the Finite Difference Method and Trinomial Trees

Kristýna Vltavská, Jaroslav Sixta: The Estimation of Final Consumption Expenditures

Lenka Vraná: Business Cycle Analysis: Tracking Turning Points

Janusz Wywiał: On Bayesian Testing in Auditing

Emília Zimková: Window Analysis of Supper-efficiency Change: Case of the Slovak Banking System ....

Beata Zmyślona: Statistical Modelling of the Impact of Diabetes on the Risk of Hospitalization 


\title{
NEW CONCEPT OF PENSION FUNDS PERFORMANCE EVALUATION
}

\author{
VLASTIMIL FARKAŠOVSKÝ \\ Matej Bel University, Faculty of Economics, Department of Finance and accounting, \\ Tajovského 10, 97590 Banská Bystrica, Slovakia \\ email: vlastimil.farkasovsky@umb.sk
}

\begin{abstract}
One of the most important issues related to the pension system is the question of its performance and level of risk. The paper deals with problem of evaluation of the Slovak pension funds performance. The paper describes inaccuracies of the present methodology used by official authorities to evaluate pension funds' performance. It is based on changes in pension unit current value, which is by law defined as a share on assets of pension fund, not a rate of return. The paper aims to present the new innovative methodology that accurately assesses the pension funds nominal and real performance including also time value of money. It is based on future value and internal rate of return computed by nonlinear iterative methods.
\end{abstract}

Key words: pension funds, performance evaluation, time value of money

DOI: $10.15611 /$ amse.2014.17.09

\section{Introduction}

Due to declining fertility and increasing life expectancy, one of the most characteristic features of modern societies is the population ageing. To face these changes, many countries introduced pension reform which included also funded pension scheme. The new one is less sensitive to demographic changes comparing to Pay-as-you-go scheme. The main goal of introduction was long-term stability and sustainability of pension system, which should be backed by appreciation of household deposits on pension accounts in private Pension fund Management Companies (PMC). Those companies should invest funds on the money and capital markets trying to maximize their performance and minimize risk.

It is important to highlight, that while the riskiness is more or less regulated (Broeders, Chen, 2013; Thomas et al. 2014), an interesting question remains how to measure the performance of the fund and its rate of return. All previous analyzes computed directly performance measures from available actual data (f.e. Banegas et al., 2013, Hunter et al. 2014) and a work dealing with problem of inaccuracies of computing appreciation derived from changes in the pension unit current value (PUCV) could not be find. Schroeder (2012) use internal rate of return to compute profitability within pay-as-you-go system. On the contrary, many scientist (see e.g. Vravec, 2008), pension management companies and other official authorities stick to the inaccurate methodology. The PUCV is also defined under the Slovak legislation (Act no. 43/2004) as a proportion of assets in the fund and certainly not as a rate of return, which brings the question whether the comparison of actual changes in 
pension unit current value (as the only and widely used method) correctly quantifies the rate of return of pension savings.

The paper is organized in 5 sections, the first of which is introductory and the last is concluding. The second section brings pitfalls of the actual methodology, showing current state of performance evaluation of pension funds in Slovakia which are based on PUCV comparison. The same problem can be found in the Czech Republic (PUCV = Di̊chodová jednotka), Poland (PUCV = Jednostka rozrachunkowa) and many other countries. The third section of the contribution is devoted to proposal of the methodology based on future value of money. The fourth section includes reached results, their economic interpretation and comparison of both approaches under research. It is proved in the paper that the proposed methodology allows calculation of the fair rate of return of the PMC clients' accounts appreciation and the possibility of comparing PMCs based on their performance.

\section{Pitfalls of current methodology and data set}

In this section, the current state of performance evaluation in the Slovak Republic is shown. PUCV is together with the net asset value ${ }^{1}$ of funds (NAV) the most tracked data reported by pension management companies. In Slovak republic, PUCV in the day of pension fund creation was set by legislation as 1 Slovak crown $(0.0332 €)$. This means that at this moment client received for every one crown levied, one pension unit, which according to Act no. 43/2004 on retirement pension savings, expresses his "share on the assets of the pension fund." Act no. 43/2004 further says that the current value of the pension unit (PUCV) at the relevant date shall be determined as "share of net asset values (NAV) of the funds and the number of all registered pension units in personal accounts of all savers on the date of calculation."

$$
P U C V=\frac{\sum_{i=1}^{n} N A V_{i}}{\sum_{i=1}^{n} P U_{i}}
$$

Where: PUCV - Pension unit current value

$\mathrm{NAV}-\mathrm{Net}$ asset value

PU - Pension units

$\mathrm{n}-$ Number of pension units

Development of PUCV for each fund type in the Slovak Republic can be seen at the following graph. Figure 1 shows a development, which is not equal with the development of performance of the pension funds. In spite of that, it is way how is often presented. Inaccuracies of this type of performance presentation can rise to tens of per cent in the longterm as will be shown in the section 4 .

\footnotetext{
${ }^{1}$ Net asset value of the pension fund is calculated as the difference between the value of pension fund assets and its liabilities
} 
In spite of this fact Figure 1 became mantra of the Slovak republic pension funds performance, when long-term development is presented ${ }^{2}$. But the only added value of this chart is to show PUCV changes and periods of different forms of PMCs regulation, not the real performance.

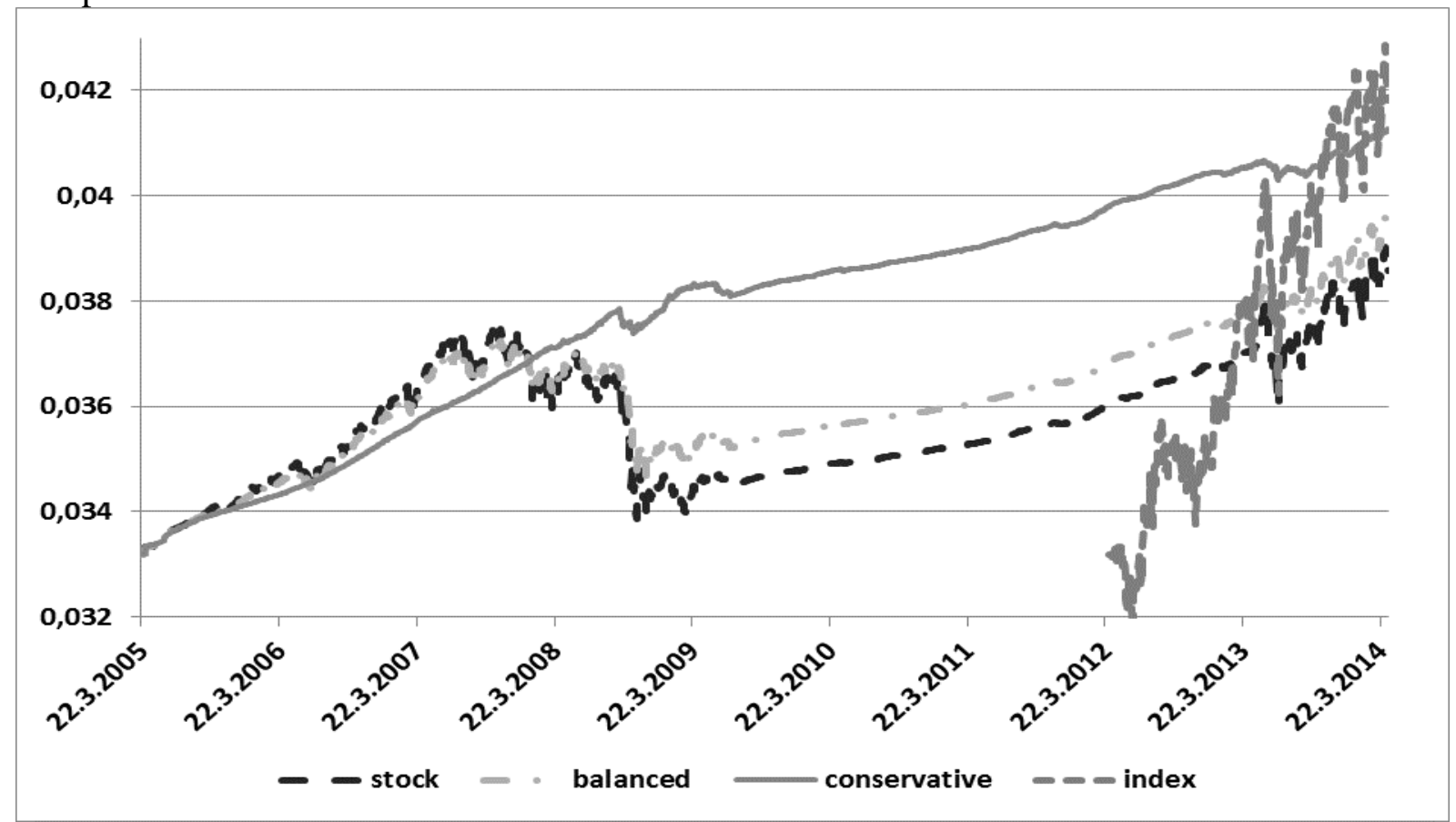

Figure 1 Development of PUCV in $€$ for different types of funds (22.3.2005-22.3.2014)

Source: Own computing based on National Bank of Slovakia data set

Till the end of 2008, development of PUCV was quite volatile and, as the result of financial crisis, PUCV dropped down dramatically. Subsequent reaction of the Slovak government in the form of regulation brought de facto restriction on investing in the stock component and the transfer of almost all funds in money market instruments and bonds for every fund type. This legislative change remained in force till $30^{\text {th }}$ April 2013, when some restrictions were released. What cannot be seen at the graph is fact that overnight the vast majority of funds were transferred to conservative funds. The share has changed from $14 \%$ to $91 \%$. Also introduction of the index fund can be seen, but its share on total NAV is negligible and in long term is always less than one percent on the total assets. Described changes and shifts in pension funds shares even more marked differences between official and real nominal annual rate of return of PMCs.

Interesting fact remains, that in spite of wide usage of the Figure 1 to illustrate performance, when official performance results are presented ${ }^{3}$, the National bank of Slovakia methodology is used, not changes, which can be seen at the Figure 1. Currently in Slovakia was established practice that changes in PUCV (at best weighted changes) are considered as

\footnotetext{
${ }^{2}$ See web portals of Slovak pension management companies. For example $<$ http://www.asdss.sk/zhodnoteniefondov $>$ or $<$ https://www.vubgenerali.sk/dochodkove-fondy/vykonnost-dochodkovych-fondov $>$

${ }^{3}$ See for example web portal of Post bank PMC

$<$ http://www.dsspabk.sk/_img/Documents/Fondy_vykonnost/fondy_vykonnost.pdf $>$
} 
the performance of pension funds in the period. Methodology of weighted changes was introduced by National Bank of Slovakia, but as will be shown, it is also inaccurate.

Inaccurate performance measurement based on changes of PUCV can be observed all over the spectrum of relevant participants (pension fund management companies $^{4}$, relevant ministries ${ }^{5}$, the media or scientific $\left.\operatorname{articles}^{6}\right)$.

The only exception in this regard was disclosed by the National Bank of Slovakia (NBS) while calculating from March 2008 to June 2009 on a daily basis the average yield of the pension fund as a moving average. Subsequently, as a result of the newly adopted legislation, the National bank of Slovakia refrained from this report in June 2009. Methodology of this calculation can be seen at Analysis of the Slovak financial sector for the year 2011 (2012).

Despite the fact that this is a change in comparison to other entities, these calculations are still only at the level of the comparing daily changes in PUCV and do not measure the actual performance of the pension fund.

In following part currently widely used methodology based on changes in PUCV are shown. Data sources for calculating pension funds' performance can be also found here. For calculating the nominal appreciation methodology based on a comparison of changes in PUCV published by the National Bank of Slovakia (Analysis of the Slovak Financial Sector, 2012, p.110) is used. It defines the average annual return on pension funds as follows: "The average annual return on pension funds is calculated as the weighted average percentage change from year to year daily values of pension units of the pension funds. Percentage annual change of pension unit daily value is calculated in units to 30. 6. 2012 ( $\left.\mathrm{PACH}_{30.6 .2012}\right)$ as follows:

$$
P A C H_{30.62012}=\left(\frac{P U C V_{30.62012}}{P U C V_{30.62011}}-1\right) * 100 \%
$$

Weight is the share of net asset value (NAV) of the fund in the sum of NAV of funds of the same type. The indicated rate of return is the nominal, which means it does not address the general rise in prices. In determining the profitability of different forms of investment are normally indicates the nominal rate of return, while calculated according to the legal standard methodology"

As we mentioned, for computing PACH, we need daily data about PUCV and NAV. Data for our calculation were obtained from database of National Bank of Slovakia for period of 9 years since the establishment of PMCs 22 ${ }^{\text {th }}$ March 2005 till $21^{\text {th }}$ March 2014, what represents 2250 business days.

\footnotetext{
${ }^{4}$ See web portals of Slovak pension management companies. For example $<$ http://www.asdss.sk/zhodnoteniefondov $>$ or $<$ https://www.vubgenerali.sk/dochodkove-fondy/vykonnost-dochodkovych-fondov $>$

5 Ministry of Labour, Social Affairs and Family of Slovak republic: http://www.employment.gov.sk/files/slovensky/socialne-poistenie-dochodkove-sporenie/dochodkovysystem/ii-pilier-starobne-dochodkove-sporenie/zhodnotenie-majetku/porovnaniedss.pdf [cit. 2014-02-21]

${ }^{6}$ See f.e. Vravec, J. 2008. Analýza dôchodkových fondov v SR. In: Národná a regionálna ekonomika 7. - Košice : TU, EkF, 2008. - ISBN 9788055300849. - pp. 938-945
} 
The problem of extracting rate of return from changes in PUCV $(\mathrm{PACH})$ is based on the fact that change in NAV ( $\triangle \mathrm{NAV})$ between two periods includes two components. First component is the increase caused by changes in total assets due to changes in the number of pension units and the second component is the change in total assets from capital appreciation in the fund without changing the number of pension units. And because PUCV is calculated from NAV in the way described, this methodology overestimate real nominal rate of return in cases of increasing NAV caused by new deposits. That is common in present situation, when there are no withdrawals of pensions (the first pensions will be paid from system only after 2015 and at that time an inflow of deposits will be higher than outflow). Current methodology is therefore correct only in the cases, when there is no change in NAV caused by inflows or outflows of PUs, what is only theoretical possibility. For clarification the case study illustrating inaccuracies of current methodology are shown.

Let us assume the case, when client deposit (DEP) is $500 €$ in the first year and $1500 €$ in the second year. Rate of return in first year is $50 \%$ p.a. and in second year $0 \%$ p.a.

Table 1 Case study assumptions

\begin{tabular}{ccccc}
\hline Time period & Deposit $(\mathbf{D E P})$ & PUCV & Bought PU & NAV \\
\hline $\mathrm{T}=0$ & $500 €$ & $1 €$ & $500 \mathrm{DJ}$ bought & $500 €$ \\
$\mathrm{~T}=1$ & & $1,5 €$ & $500 \mathrm{PU}$ owned & $750 €$ \\
$\mathrm{~T}=1$ & $1500 €$ & $1,5 €$ & 1000 PU bought & $2250 €$ \\
$\mathrm{~T}=2$ & & $1,5 €$ & 1500 PU owned & $2250 €$
\end{tabular}

Source: Own processing

If there is a chart showing changes in PUCV, which is now in Slovak conditions using for illustrating performance, it would show 50\% appreciation between two years, so it means $\mathrm{i}=25 \%$ p.a. When calculating the annual nominal rate of return by widespread used methodology of National Bank of Slovakia, the result would be $i=12.5 \%$ p.a. Lower rate of return is caused by calculating with weights. But if $12.5 \%$ p.a. is correctly calculated rate of return between $\mathrm{T}=0$ and $\mathrm{T}=2$, the result of following equation:

$$
D E P_{t=0} * i^{2}+D E P_{t=1}^{*} i=N A V_{t=2}
$$

would be 2250 , what is NAV at the period $\mathrm{T}=2$. Unfortunately, the result is $2320 €$. According to methodology proposal presented in the next section, the result would be exactly $2250 €$.

In the next sections we proposed methodology concept, which respects time value of money and calculating correct average annual nominal rate of return. Modification by which real rate of return is calculated is also shown. Section includes possibilities of future exploitation too. At the fourth section, the chart comparing both methodologies, where 
actually incurred inaccuracies over time can be seen and also the real actual rates of return of selected types of funds.

\section{Proposal of methodology based on future value of money}

The above mentioned problem can be solved when the NAV changes in the component of gains due to appreciation of assets in the fund are cleaned off and the modified internal rate of return method based on net future value of money is used.

$$
\sum_{k=0}^{K}\left(\left(N A V_{k+1}{ }^{-} N A V_{k}^{*}\left(1+\frac{P U C V_{k+1}-P U C V_{k}}{P U C V_{k}}\right)\right) *(1+I R R)^{\frac{k}{365}}\right)=0
$$

IRR - internal rate of return (equal to actual nominal rate of return of pension fund)

$\mathrm{K}$ - number of business days till period of computing

$\mathrm{k}$ - index of days

$\mathrm{NAV}_{\mathrm{k}}-\mathrm{Net}$ asset value of fund at business day $\mathrm{k}$

$\mathrm{NAV}_{\mathrm{k}+1}-\mathrm{Net}$ asset value of fund at business day $\mathrm{k}+1$

Because of the fact, that till today we have 2250 business days, to compute actual annual nominal interest rate (IRR) for one pension fund and one day, the system of 2250 nonlinear equations for IRR have to be solved. For this reason results are computed by widely used iterative numerical methods using generalized reduced gradient algorithm for optimizing nonlinear problems. More information about methodology of computing can be found in Lasdon, Waren et al. (1998). Accuracy of computing is set to $0.00001 \%$.

To compute real annual rate of return, augmented equation (4) for IRR by inflation $\left(\pi_{\mathrm{k}}\right)$ as follows in equation (5) is proposed. Inflation is incorporated by use of official data of Statistical office of the Slovak Republic.

$$
\sum_{k=0}^{K}\left(\left(N A V_{k+1}-N A V_{k}^{*}\left(1+\frac{P U C V_{k+1}-P U C V_{k}}{P U C V_{k}}\right)\right) *(1+I R R)^{\frac{k}{365} * \pi_{k}}\right)=0
$$

The proposed method can be used for all types of mandatory pension funds, voluntary pension funds or mutual funds. Procedure can be also used to calculate the rate of return of the whole funded pension pillar, which has not yet been calculated. The rate of return calculated by the proposed methodology could be compared with estimated implicit rate of return of the Pay-as-you-go pension pillar, thus according to Aaron-Samuelson conditions, advantage of funded pillar introduction may be verified. The procedure can also be used to calculate the individual clients' rates of return, who currently are not informed about the appreciation or depreciation of their property in PMCs funds.

\section{Results and discussion}

The outcome of the research is defining of inaccuracies arising from using a official methodology of computing the nominal and real appreciation of pension funds. Moreover, 


\section{$12 \backsim$ APPLICATIONS OF Mathematics And Statistics IN ECONOMICS}

nominal and real performance according to proposed methodology that accurately assesses the pension funds is discussed. At the Figure 2 nominal and real rate of returns can be observed for each type of pension funds and also for the whole funded pension scheme for the last 9 years between 22th March 2005 and 21th March 2014.

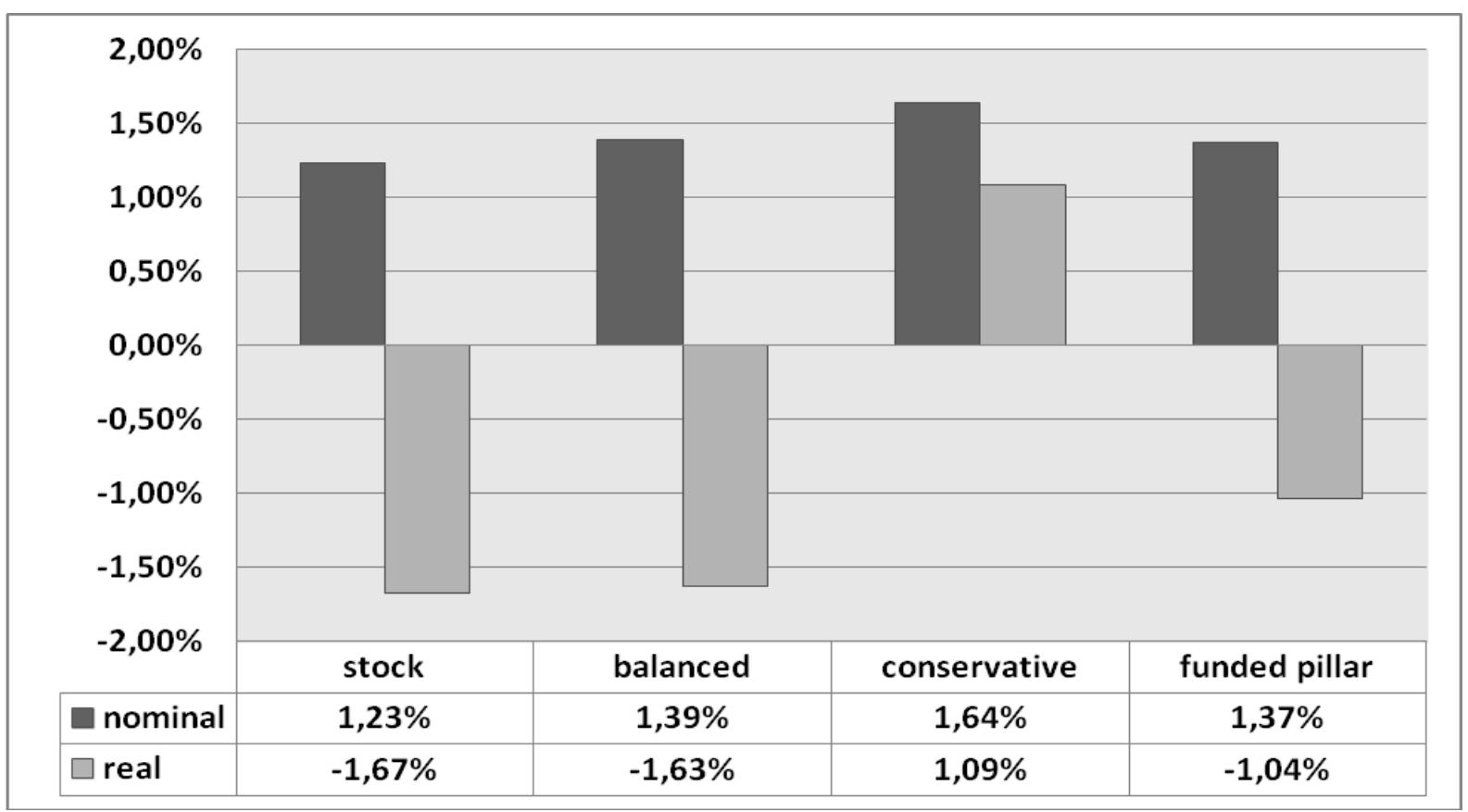

Figure 2 Development of PUCV in $€$ for different types of funds

Source: Own computing based on National Bank of Slovakia data set

Figure 2 shows that assets in all types of funds were nominally appreciated in range of $1,23 \%-1,64 \%$, but real appreciation in stock and balanced funds, which managed the vast majority of assets in the past fall to negative rates of returns, what influenced whole funded pension pillar. In spite of the fact, that inflation influenced all type of funds, we can see only small influence on conservative funds. That is caused by the fact that proposed methodology considers appreciation of every euro in a fund during the time and because of great shift from stock and balanced funds to conservative in the last year characterized by low inflation rate.

The overall results are very negative. Real depreciation of clients' money in a long term ( 9 years) can be seen. The level of approximately $1 \%$ p.a. depreciation can cumulatively in continuation of current trend means dramatic loss of purchasing power of future pensioners. This can be dangerous from long-term sustainability of pension system, which already generates high deficits, which are rehabilitated from the state budget. Úradníček and Zimková (2013) calculated that threshold point for Visegrad countries on the level of $51 \%$ debt to GDP is already broken in the Slovak republic. From this reason sustainability is threatened and there is no more space for other debt increase.

Finally, at the last paragraph inaccuracies as a consequence of using current methodology are shown. In the next table can be seen comparison between official results of pension funds nominal performance and real results of pension funds performance. All rates of return are computed from beginning of pension fund till $4^{\text {th }}$ April 2014. 
Table 2 Comparison of inaccuracies between $\triangle \mathrm{PUCV}$ methodology and IRR methodology

\begin{tabular}{|c|c|c|c|c|c|}
\hline \multirow{2}{*}{ PMC } & \multirow{2}{*}{ PUCV } & \multirow{2}{*}{ NAV } & \multicolumn{3}{|c|}{$\begin{array}{l}\text { Nominal appreciation p.a. } \\
\text { (from 22.3.2005 till 4.4.2014) }\end{array}$} \\
\hline & & & $\triangle \mathrm{PUCV}$ & IRR & difference \\
\hline \multicolumn{6}{|c|}{ Stock funds } \\
\hline AEGON & $0,036909 €$ & $46620186 €$ & $1,27 \%$ & $0,71 \%$ & $0,56 \%$ \\
\hline ALLIANZ & $0,039129 €$ & $165457556 €$ & $2,02 \%$ & $1,49 \%$ & $0,53 \%$ \\
\hline AXA & $0,038177 €$ & $149869648 €$ & $1,65 \%$ & $1,07 \%$ & $0,58 \%$ \\
\hline PABK & $0,038305 €$ & $39375635 €$ & $1,70 \%$ & $1,50 \%$ & $0,20 \%$ \\
\hline ING & $0,038258 €$ & $61368462 €$ & $1,69 \%$ & $1,31 \%$ & $0,38 \%$ \\
\hline VúB & $0,040380 €$ & $43485369 €$ & $2,33 \%$ & $1,70 \%$ & $0,63 \%$ \\
\hline \multicolumn{6}{|c|}{ Balanced funds } \\
\hline ČSOB & $0,038694 €$ & $14047240 €$ & $1,76 \%$ & $1,58 \%$ & $0,18 \%$ \\
\hline PABK & $0,038552 €$ & $20923274 €$ & $1,74 \%$ & $1,52 \%$ & $0,22 \%$ \\
\hline VúB & $0,040549 €$ & $21537334 €$ & $2,35 \%$ & $1,88 \%$ & $0,47 \%$ \\
\hline \multicolumn{6}{|c|}{ Conservative funds } \\
\hline AEGON & $0,041947 €$ & $530653761 €$ & $2,62 \%$ & $1,83 \%$ & $0,79 \%$ \\
\hline ALLIANZ & $0,040728 €$ & $1765481754 €$ & $2,28 \%$ & $1,53 \%$ & $0,75 \%$ \\
\hline AXA & $0,040784 €$ & $1371573493 €$ & $2,30 \%$ & $1,75 \%$ & $0,55 \%$ \\
\hline PABK & $0,042433 €$ & $270910924 €$ & $2,72 \%$ & $2,43 \%$ & $0,29 \%$ \\
\hline ING & $0,041119 €$ & $545605920 €$ & $2,40 \%$ & $1,06 \%$ & $1,33 \%$ \\
\hline VúB & $0,042474 €$ & $821465357 €$ & $2,76 \%$ & $2,76 \%$ & $0,00 \%$ \\
\hline
\end{tabular}

Source: Own processing based on data from National Bank of Slovakia

Table 2 displays values of PUCV and NAV at $4^{\text {th }}$ April 2014. According to NAV, great share of conservative funds can be observed, what is caused by mentioned shift. As was also mentioned before, current methodology overestimate actual nominal rate of return, when only in the case of VÚB Generali conservative pension fund is the official rate of return on the level of actual. This fund at the same time achieves highest appreciation rate.

The highest difference at $4^{\text {th }}$ April 2014 was recorded by ING conservative fund. During past periods, differences between methodologies were higher, but in spite of this there are still substantial differences.

On the last chart the comparison between nominal rate of return computed by proposed methodology and nominal rates of return which arise as the result of PUCV comparison and which are officially presented by official institutions like PMCs is presented. As was mentioned, from 30 $30^{\text {th }}$ April 2013 a great amount of funds was shifted to the conservative pension funds. This was reason, why every change in this fund gained on importance and reciprocally stock and balanced fund loss on importance. From this reason at the Figure 3 relatively large volatility based on old methodology can be seen. Those changes are not relevant for long term performance, because in this time only small amount of money was appreciated in these funds. So as can be seen on the line of stock and balanced pension funds calculated according to proposed methodology draft, this line remains unchanged, while line of PUCV recorded a sharp changes. 


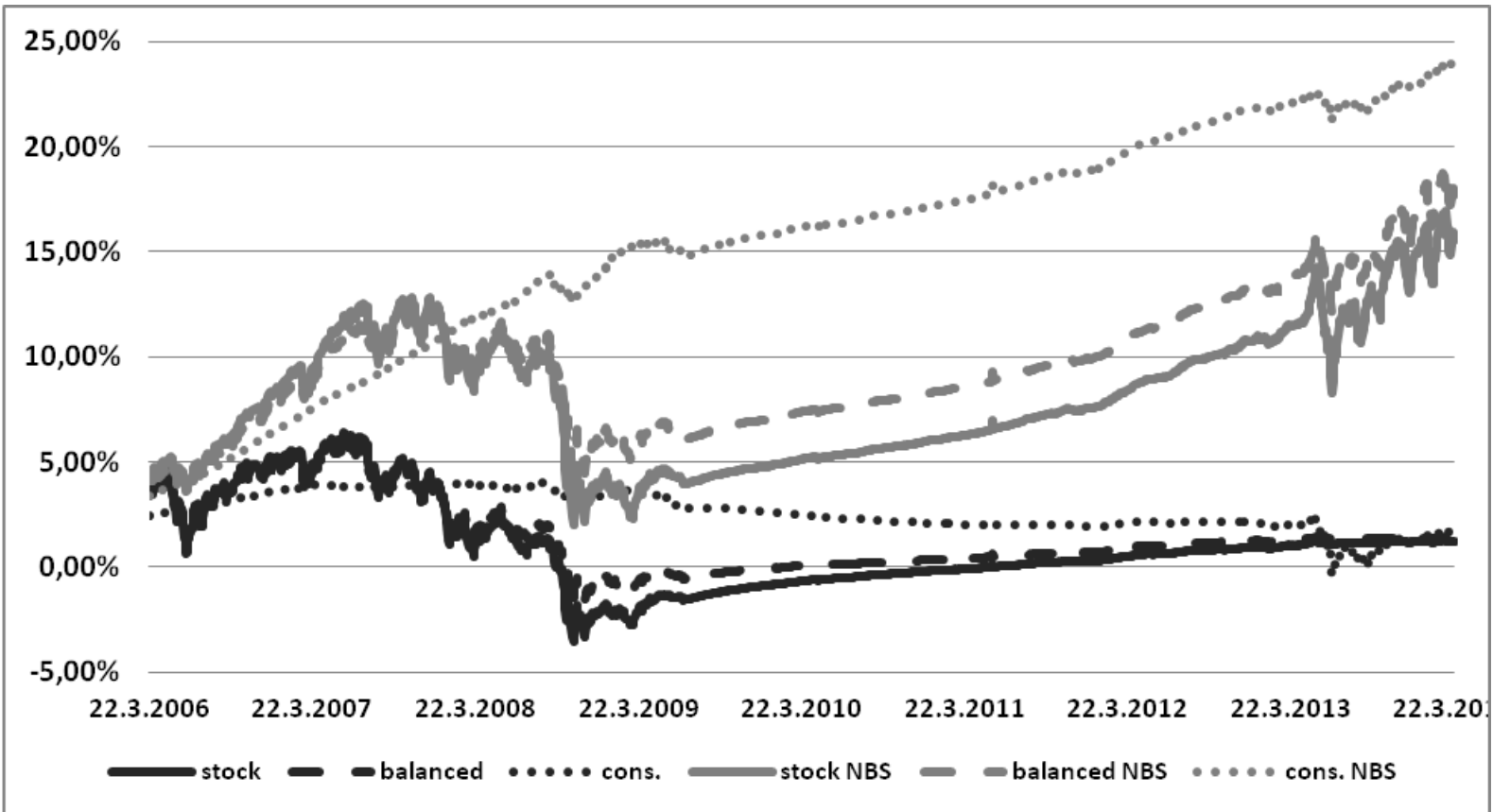

Figure 3 Development of PUCV and actual annual nominal rate of return of selected funds between $22^{\text {th }}$ March 2005 and $21^{\text {th }}$ March 2014

Source: Own computing based on National Bank of Slovakia data set

The contribution brings important and unpublished results which are beneficial to the national regulator of the pension funds, to depositors involved into the funded pension pillar, pension funds management companies and to policy makers. Methodology can be used in many countries dealing with the same problem.

\section{Conclusion}

Pension reform was one of the most challenging tasks for Slovak government from period of its independence. Ongoing and predicted deficits of the pension scheme under the influence of demography became unsustainable. The answer to these questions should be change in pension design and introduction of mixed system, containing the funded and pay-as-you-go pillar. During this relatively long period, there have been numerous analyzes, published results evaluating the performance of the funded pillar, but all previous analyzes were based on monitoring changes in PUCV. The aim of this work is the assessment of the current state of performance measurement, pointing out inaccuracies arising from using the official methodology and proposing a solution to this problem, which can accurately assess pension fund appreciation. Proposed methodology of pension funds rate of returns evaluation was shown in section 3. In the end, exact value of the nominal appreciation of pension funds was calculated and the volume of inaccuracies was shown. Contribution and originality of the work lies in the creation of a methodology, which accurately assess the nominal and also real performance of pension funds.

New methodology proposal allows the calculation of fair rate of return of an individual client account in PMC, or the possibility of comparing PMCs based on their performance. Procedure can be also used to compute the rate of return of the whole funded pension pillar, which has not yet been calculated and could be compared with estimated implicit rate of 
return of the Pay-as-you-go pension pillar, thus according to Aaron-Samuelson conditions, advantage of funded pillar introduction may be verified. Equation (4) can also be enriched by calculating gross rate of return including also fees, or inflation to calculate real performance.

The contribution brings important and unpublished results which are beneficial to all economic subjects involved into national pension system.

\section{References}

1. Act no. 43/2004 on retirement pension savings. [cit. 21-03-2014] www.zbierka.sk/sk/predpisy/43-2004-z-z.p-7635.pdf

2. BANEGAS, A., GILLEN, B. et al. 2013. The cross section of conditional mutual fund performance in European stock markets. In Journal of Financial economics, 2013, pp. 239-272.

3. BROEDER, D., CHEN, A. 2013. Pension benefit security: A comparison of solvency requirements, a pension guarantee fund, and sponsor support. In Journal of Risk and Insurance, 2013, vol. 80, pp. 239-272.

4. HUNTER, D. et al. 2014. Mutual fund performance evaluation with active peer benchmarks. In Journal of Financial economics, 2014, vol. 112, pp. 1-29.

5. LASDON, L. - WAREN, A. et al. 1998. Design and use of the Microsoft Excel Solver. In: Interfaces, 1998. pp. 29-55. ISSN 0092-2102

6. NATIONAL BANK OF SLOVAKIA. 2012. Analysis of the Slovak financial sector for the year 2011. [cit. 21-02-2014] http://www.nbs.sk/_img/Documents/_Dohlad/ORM/ Analyzy/ASFS_2011.pdf

7. SCHROEDER, C. 2012. Profitability of pension contributions - evidence from real-life employment biographies. In: Journal of pension economics and finance, 2012, vol. 11, pp. 311-336.

8. THOMAS, A., SPATARO, R., NANDITHA, M. 2014. Pension funds and stock market volatility: An empirical analysis of OECD countries. In Journal of Financial Stability. 2014, vol. 80, iss. 2, pp. 92-103.

9. ÚRADNÍČEK, V., ZIMKOVÁ, E. 2013. Debt and Growth in the Visegrad Countries: Threshold Analysis. In Acta Aerarii Publici : Banská Bystrica, vol. 10. In press. ISSN 1336-8818

10. VRAVEC, J. 2008. Analýza dôchodkových fondov v SR. In Národná a regionálna ekonomika 7. - Košice : TU, EkF, 2008. - ISBN 9788055300849. pp. 938-945 